\title{
BIOGENIC AND PHYSICOGENIC AGGREGATES UNDER DIFFERENT CROPS WITH BLACK OAT IN NOVA FRIBURGO, BRAZIL ${ }^{1}$
}

\author{
SANDRA SANTANA DE LIMA ${ }^{2}$, MARCOS GERVASIO PEREIRA ${ }^{2 *}$, EDUARDO CARVALHO DA SILVA NETO ${ }^{2}$, \\ DOUGLATH ALVES CORRÊA FERNANDES ${ }^{2}$, ADRIANA MARIA DE AQUINO ${ }^{3}$
}

\begin{abstract}
The objective of this study was to evaluate the efficiency of black oat (Avena strigosa Schreb) crops in recovering soil aggregation, and quantify the nutrient contents in aggregates considering their formation pathways (biogenic and physicogenic) in crop areas in a mountains environment in the municipality of Nova Friburgo, RJ, Brazil. The landscape was stratified into two sections for the study: upper, two areas with black oat crops, one fertilized and one not fertilized one not fertilized, and one adjacent forest area representing the original soil conditions; and lower: one fertilized area with black oat, and one fertilized area with black oat intercrops with oilseed radish (Raphanus sativus L.) and vetch (Vicia sativa L.), and one adjacent forest area representing the original soil conditions. The aggregates were separated according to their formation pathways, quantifying the weight percentage of each formation pathway. The aggregate stability and nutrient and organic carbon contents were evaluated. The fertilized area in the upper section had the highest biogenic aggregate percentage, which was associated with the highest total organic carbon contents, and soil fertility. This area also had the highest weighted mean diameter (WMD) and geometric mean diameter (GMD) of aggregates. The intercrop area in the lower section had the highest biogenic aggregate percentage and the lowest $\mathrm{P}, \mathrm{Ca}^{+2}, \mathrm{Mg}^{+2}$, and $\mathrm{K}^{+}$contents in the aggregates. The management systems affected the aggregate formation pathways. Morphological classification is an important tool for the monitoring of soil management. The black oat crops increased the biogenic aggregate formation, which become reservoir of nutrients.
\end{abstract}

Keywords: Soil cover plants. Aggregate biogenesis. Environmental disaster.

\section{AGREGADOS BIOGÊNICOS E FISIOGÊNICOS SOB DIFERENTES CULTIVOS COM AVEIA PRETA NO MUNICÍPIO DE NOVA FRIBURGO, RJ}

RESUMO - Avaliou-se a eficiência da aveia preta na recuperação da agregação do solo e quantificou-se os teores dos nutrientes nos agregados biogênicos e fisiogênicos em áreas de cultivo de Nova Friburgo, RJ. A paisagem foi estratificada nas secções: superior - com o emprego de aveia preta, adubada e outra não adubada; e inferior: com aveia preta adubada, outra com consórcio de aveia preta, nabo forrageiro e ervilhaca com adubação. Ambas as secções tinham área adjacente de floresta. Os agregados foram separados quanto às vias de formação quantificando-se a porcentagem de massa em cada via de formação. Foram analisados: estabilidade dos agregados, teores de nutrientes e conteúdo de carbono orgânico. $\mathrm{Na}$ parte superior, na área adubada verificou-se a maior porcentagem de agregados biogênicos associada a maiores valores de carbono orgânico total, e fertilidade. Nessa área também foram observados maiores valores de diâmetro médio ponderado e o diâmetro médio geométrico dos agregados. Na parte inferior, na área de consórcio foi quantificada a maior porcentagem de agregados biogênicos e quantificados os menores teores de $\mathrm{P}, \mathrm{Ca}^{+2}, \mathrm{Mg}^{+2} \mathrm{e} \mathrm{K}^{+}$. Os sistemas de manejo influenciaram nas vias de formação dos agregados. A classificação morfológica representa uma importante ferramenta para o monitoramento do manejo do solo. A aveia preta promoveu o aumento da formação dos agregados biogênicos, os quais se comportaram como compartimentos de reservas de nutrientes.

Palavras-chaves: Plantas de cobertura. Biogênese de agregados. Desastre ambiental.

\footnotetext{
${ }^{*}$ Corresponding author

${ }^{1}$ Received for publication in $03 / 25 / 2019$; accepted in $03 / 25 / 2020$.

Paper extracted from the Post-doctorate of the first author.

${ }^{2}$ Institute of Agronomy, Department of Soils, Universidade Federal Rural do Rio de Janeiro, Seropédica, RJ, Brazil; sandra.biologa@hotmail.com - ORCID: 0000-0003-3599-8344, mgervasiopereira01@gmail.com - ORCID: 0000-0002-1402-3612, netocseduardo@yahoo.com.br - ORCID: 0000-0001-6986-1376, douglathalves@hotmail.com - ORCID:0000-0003-2920-7630.

${ }^{3}$ Empresa Brasileira de Pesquisa Agropecuária, Seropédica, RJ, Brazil; adriana.aquino@embrapa.br - ORCID: 0000-0003-3718-4512.
} 


\section{INTRODUCTION}

The impacts of an environmental disaster occurred in January 2011 in the municipality of Nova Friburgo, mountain range region of the state of Rio of Janeiro, Brazil, resulted in decreases in agricultural areas, affecting more of $60 \%$ of areas grown with olericulture (SEAPEC-RJ, 2011). The use of soil cover plants started in the region considering this situation and the need for recovering crop yields of the affected areas. This practice results in improvements to soil conservation by decreasing erosive processes, due to its positive effects on soil physical, chemical, and biological attributes (BARRADAS et al., 2001; BARROS; GOMIDE; CARVALHO, 2013).

Soil cover plants extract nutrients from deeper soil layers through their root system, making them available in upper layers, after their decomposition and mineralization (CRUSCIOL et al., 2008). One of the beneficial effects of using soil cover plants is the increase in soil organic matter content, which favors soil aggregation and biological activity (CUNHA et al., 2011; BARROS; GOMIDE; CARVALHO, 2013). Soil cover plants have higher efficiency in recovery soil chemical and physical attributes. Plants of the Fabaceae family, for example, have low $\mathrm{C}$ to $\mathrm{N}$ ratio, mainly due to their biological nitrogen fixation; thus, their organic matter decomposes rapidly. Moreover, grasses (Poaceae) have high yield and large root systems. Thus, black oat (Avena strigosa Schreb) begun to be adopted by farmers in the study region and included in crop systems to increase soil cover (BARRADAS et al., 2001; MELO et al., 2011), mainly between crop seasons.

Soil preparation systems with cover plants have significant effect on aggregation and water and air fluxes (CUNHA et al., 2011). The expectative of using soil cover plants is the decrease in soil turning and increases in addition of carbon. Higher carbon contents contribute to macroaggregate formation due to the higher root system densities and release of organic exudates to the soil (VEZZANI; MIELNICZUK, 2011; BRANDÃO; SILVA, 2012). Soil structure affects edaphic conditions, such as soil water movement and retention, erosion, nutrient cycling, and root penetration, and crop yield (BRONICK; LAL, 2005; TAVARES FILHO et al., 2012). A good soil structure present stable aggregates, with porosity that ensures water storage, gas exchange, and root development (AL-KAISI; DOUELLE; KWAW-MENSAH, 2014).

Aggregates consist of a set of soil particles with defined form and size forming a structural unit
(BOCHNER et al., 2008). Six et al. (2002) proposed two origin for soil macroaggregate, according to their formation process: structures created by ecosystem engineers (earthworms, ants, and termites), and stabled by secondary microaggregation and cluster of microbial microaggregates in greater macroaggregate structures. Later studies differed structures by morphological patterns, and formation pathways, adopting the terms biogenic, for aggregates of biological origin, and physicogenic, for those formed by soil physical and chemical processes (BATISTA et al., 2013; LOSS et al., 2017).

The evaluation of soil structural quality can be used to measure the sustainability of soil use and management systems (DEMARCHI; PERUSI; PIROLI, 2011), and shows that different soil managements promote different changes in soil attributes, affecting aggregation (LOSS et al., 2014). Morphological differences of aggregates can be found between different management systems, depending on the dominant formation pathway (PULLEMAN; MARINISSEN, 2004; FERNANDES et al., 2017). Biogenic aggregates are, in general, related to well-structured soils that can support a rich fauna community (FERREIRA et al., 2020; MELO et al., 2019; LOSS et al., 2017; SILVA NETO et al., 2016). Therefore, biological aggregation is an indicator of soil quality.

In this context, the objective of this study was to evaluate the efficiency of black oat (Avena strigosa Schreb) crops to improve soil structure by analyzing the soil aggregation, and quantifying the nutrient contents in aggregates, considering their formation pathways (biogenic and physicogenic) in crop areas in a mountains environment in the municipality of Nova Friburgo, RJ, Brazil.

\section{MATERIAL AND METHODS}

The study was conducted in a mountains environment in the municipality of Nova Friburgo, RJ, Brazil, in slope areas recovering from an environmental disaster, with conservationist production systems practiced in the region, and in two areas of secondary forest, with different soil classes (Figure 1). The areas were selected considering two extremes of the mountains landscape: three areas in the upper section of the landscape and three in the lower section. Each area had approximately 1.0 hectare, distant approximately 100 meters from each other, and approximately $2 \mathrm{~km}$ between the upper and lower sections. 


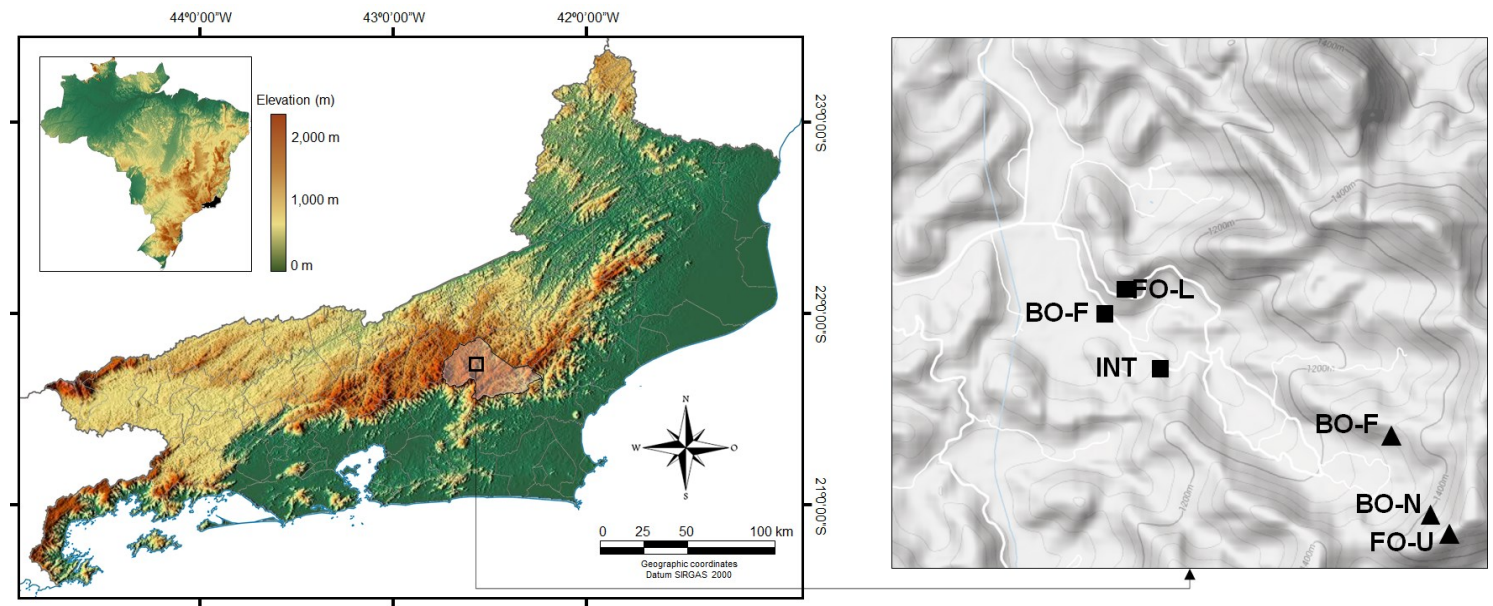

Figure 1. Location of the study areas in the municipality of Nova Friburgo, state of Rio de Janeiro, Brazil. Squares refer to areas in the lower section of the landscape, and triangles refer to areas in the upper section of the landscape. BO-F = black oat - fertilized, BO-N = black oat - not fertilized, INT (black oat-oilseed radish-vetch intercrop), FO-L (Forest area - lower section), FO-U (Forest area - upper section).

The upper section of the landscape presented altitudes of 1.300 to $1.350 \mathrm{~m}$, and slightly wavy relief ( $3 \%$ to $8 \%$ slope), soils with low pedogenetic development level, as Inceptisols, and soils with high pedogenetic level, as Ultisols. The land use history shows that the crop areas sampled (1 and 2) had not been affected, but the farmers adopted a soil conservationist management after the environmental disaster in Nova Friburgo. Area 1 (BO-N; $22^{\circ}$ $17^{\prime} 41.6^{\prime \prime S}$ and $42^{\circ} 37^{\prime} 89.7^{\prime \prime} \mathrm{W}$ ) has being managed with black oat crops since late 2011. The soil is prepared annually with plowing by the end of the winter and the black oat is planted without any soil fertilization. The black oat is killed with herbicide (Glyphosate; Roundup WG, $720 \mathrm{~g} \mathrm{~kg}^{-1}$ at $1.5 \mathrm{~kg}$ c.p. $\mathrm{ha}^{-1}$ ) before the plowing. Area 2 (BO-F; $22^{\circ}$ $17^{\prime} 43.2^{\prime \prime S}$ and $42^{\circ} 37^{\prime} 89.8^{\prime \prime S}$ ) is also managed with black oat crops since 2011, with equal soil preparation to Area 1. However, the soil of this area was fertilized with $1 \mathrm{Mg} \mathrm{ha}^{-1}$ of NPK (4-14-8). A Secondary Atlantic Forest fragment area in the upper section without record of anthropogenic action in the last 60 years was also sampled $\left(22^{\circ} 17^{\prime} 0.39^{\prime \prime} \mathrm{S}\right.$ and $42^{\circ} 37^{\prime \prime} 0.99 " \mathrm{~W}$ ).

The slope conditions and soils in the lower section of the landscape (altitudes between 1.024 and $1.056 \mathrm{~m}$ ) were similar to those in the upper section, with expression of Inceptisols and Ultisols. Area 1 (BO-F; 22 ${ }^{\circ} 17^{\prime} 13.9^{\prime \prime}$ and $42^{\circ} 39^{\prime} 56.8^{\prime \prime} \mathrm{S}$ ) is grown with black oat (Avena strigosa) as soil cover crop since late 2011. This area was totally buried in January 2011, due to overflows of water bodies, and remained flooded for 2 months with large depositions of sand (ROSSI et al., 2015). The black oat is killed with herbicide as in Area 1 in the upper section, but the sowing (broadcasting of seeds) was done without soil turning. The soil fertilization consisted of $15 \mathrm{Mg} \mathrm{ha}^{-1}$ of poultry litter and 1 $\mathrm{Mg} \mathrm{ha}^{-1}$ of NPK (4-14-8). Area 2 (INT; $22^{\circ} 17^{\prime} 18.9^{\prime \prime} \mathrm{S}$ and $\left.42^{\circ} 39^{\prime} 20.1^{\prime \prime} \mathrm{W}\right)$ is managed since 2013 with black oat, oilseed radish (Raphanus sativus L.) and vetch (Vicia sativa L.) intercrops. The soil fertilization consisted of $1 \mathrm{Mg} \mathrm{ha}^{-1}$ NPK (4-14-8). A secondary forest fragment was also sampled; this area was cut by a road, and the collection site was at 15 meters from the road, near the crop areas $\left(22^{\circ}\right.$ 16'98.3"S and 42 $\left.39^{\prime} 34.5^{\prime \prime} \mathrm{W}\right)$.

The samples were collected in November 2014. Mini-trenches were opened in each area with the aid of a spade, and undisturbed soil samples of the $0-0.10 \mathrm{~m}$ layer were collected, sieved in the field using a set of sieves of 9.7 and $8.0 \mathrm{~mm}$, up to the obtaining of approximately $1 \mathrm{~kg}$ of sieved soil. Aggregate formation pathways were identified using aggregates contained in the interval of the sieves, between 8.0 and $9.7 \mathrm{~mm}$. The aggregates were examined under a magnifier, manually separated according to the definitions of Bullock et al. (1985), and classified by morphological standards as: physicogenic, when presenting angular forms; and biogenic, when presenting round forms (which are caused by the intestinal tract of individuals of the soil macrofauna, mainly from the Oligochaeta subclass - earthworms) or root activity. The relative contribution in weight of aggregates was determined using $200 \mathrm{~g}$ of aggregates.

Part of the aggregates separated according to their formation pathways was used to evaluate the aggregate stability through wet sieving, whose results were used to calculated the weighted mean diameter (WMD) and geometric mean diameter (GMD) of aggregates (DONAGEMA et al., 2011). The aggregates were passed through a $2.00 \mathrm{~mm}$ mesh sieve, according to their formation pathways. These sieved soils were analyzed for $\mathrm{pH}$ in water, $\mathrm{Ca}^{+2}+\mathrm{Mg}^{+2}, \mathrm{Al}^{+3}, \mathrm{~K}^{+}, \mathrm{Na}^{+}, \mathrm{H}+\mathrm{Al}$, and $\mathrm{P}$, and their total organic carbon (TOC) contents was evaluated according to Yeomans and Bremner (1988). 
The data were analyzed considering the different topographical positions of the areas; the upper and lower sections were analyzed separately. Considering that the soil and slope conditions of each part of the landscape were similar, a completely randomized design was used, with split-plot arrangement. The forest areas of both parts of the landscape were considered as reference areas, therefore, they were not considered for statistical analysis. The data were subjected to tests of normality and homogeneity of variance by the Shapiro-Wilk and Bartlett tests, respectively. The data of the variables that not met the assumptions of ANOVA $\left(\mathrm{Al}^{+3}, \mathrm{Ca}^{+2}\right.$, sum of bases for the upper, and $\mathrm{Al}^{+3}, \mathrm{~K}^{+}$for the lower section) were subjected to transformation by the Box and Cox method and a new analysis could be done, and the means of factors that presented significant difference were compared by the Bonferroni $\mathrm{T}$ test $(p<0.05)$, using the software R 3.1.1 (R DEVELOPMENT CORE TEAM, 2015) and the package ExpDes.pt (FERREIRA; CAVALCANTI; NOGUEIRA, 2013).

\section{RESULTS AND DISCUSSION}

The analysis of the mean weight percentage of aggregates of each formation pathway (biogenic and physicogenic) showed significant differences $(p<0.05)$ between the upper and lower section of the landscape (Figure 2). The area with black oat, fertilized (BO-F), in the upper section had higher mean percentage of biogenic aggregates (52\%), whereas the area with black oat, not fertilized (BO$\mathrm{N})$, had higher mean percentage of physicogenic aggregates $(53 \%)$. The mean percentage of biogenic aggregates in the BO-F area was higher than that in the BO-N. However, a higher mean percentage of physicogenic aggregates was found in the BO-N area.
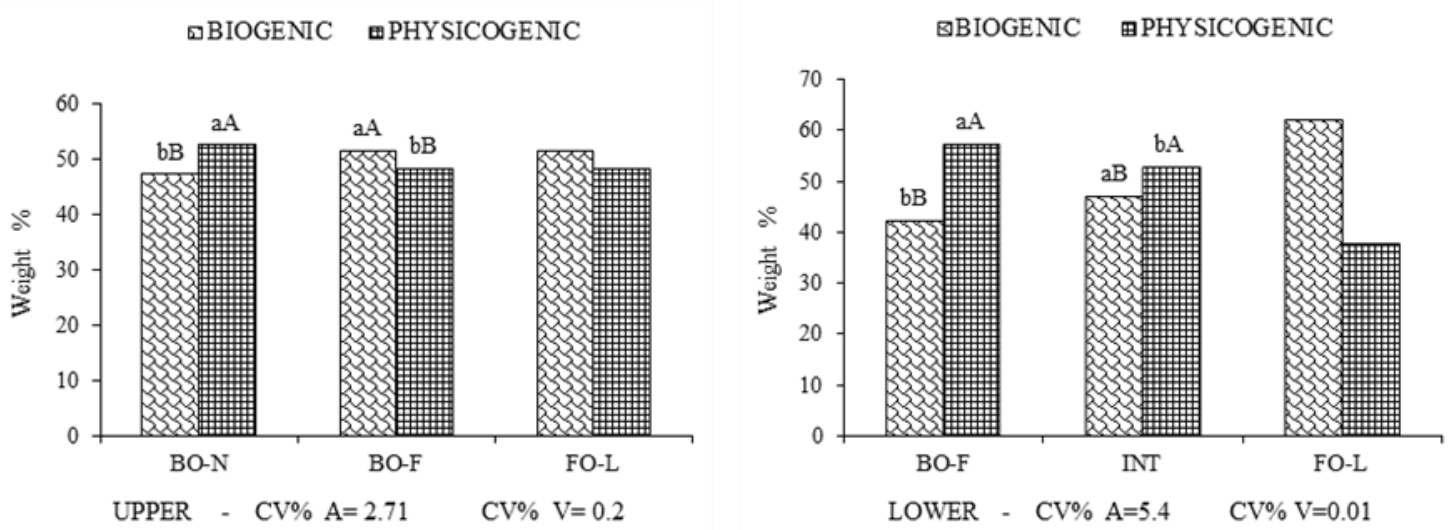

Figure 2. Weight percentage of aggregates, according to their formation pathways in crop and forest areas. $\mathrm{BO}-\mathrm{N}=$ black oat - not fertilized, BO-F = black oat - fertilized, INT (black oat-oilseed radish-vetch intercrop), FO-U (Forest area - upper section), FO-L (Forest area - lower section). Means followed by the same lowercase letter comparing formation pathways between areas, or uppercase letter comparing formation pathways within the areas are not different by the Bonferroni test $(\mathrm{p}<0.05) . \mathrm{CV}=$ coefficient of variation; $\mathrm{A}=$ areas; $\mathrm{V}=$ formation pathways.

The greater amount of biogenic aggregates in the BO-F area can be related to the increase in biological activity due to the soil fertilization before the crop implementation, which favored the black oat root system development. The organic matter contribution by the plant shoot and root system favors the development of soil micro and macroorganism populations present in the rhizosphere and, thus, contributes to biogenic aggregate formation (BRONICK; LAL, 2005). In addition, the action of the root system favors the aggregate formation by release compounds that have agglutinating effect of individual particles in the soil. Dense root systems combined with constant renewal of the root system of grasses increase the addition of organic matter to the soil and biogenic aggregate formation (PULLEMAN et al., 2005).
The biogenic and physicogenic aggregates found in the BO-F area presented similarity with those found in the forest area in the upper section of the landscape used as reference. This indicates that the black oat crop and the soil fertilization contributed to the maintenance of soil quality, favoring aggregate biogenesis. According to Silva et al. (2013), black oat crops increase soil fauna abundance and diversity due to its beneficial effects in maintaining plant residues on the soil surface, which results in a more favorable environment to the survival of some groups of organisms. Changes in land use and management practices change biogenic and physicogenic aggregate formation processes (FERREIRA et al., 2020). Therefore, monitoring management practices through evaluation of aggregate formation pathways can be a strategy to 
control soil degradation.

The black oat-oilseed radish-vetch intercrop area (INT) had the highest $(p>0.05)$ percentage of biogenic aggregates (47\%) in the lower section of the landscape, and the highest percentage of physicogenic aggregates was found for the BO-F area $(58 \%)$. The lower percentage of biogenic aggregates in the BO-F area can be related to the environmental impact caused by a river overflow in 2011. According to Rossi et al. (2015) the soil in this area was buried by a large volume of low-fertility sediments. This compromised not only the soil structure, but the biological activity and, consequently, the formation pathway of biogenic aggregates. According to Loss et al. (2014), biogenic aggregates are more sensitive to impacts caused by natural and anthropogenic processes and, thus, more reliable indicators of soil quality.

The comparison of aggregate formation pathways within each area in the lower section showed that the means of physicogenic aggregates of the BO-F (58 \%) and INT (53\%) were high; however, the biogenic aggregates in the forest area used as reference was higher (62\%). The forest area presented termite nests in the soil, which probably contributed to the higher amount of biogenic aggregates. In addition, soils of the Atlantic Forest usually present large amounts and diversity of litterfall, roots, and biological activity (SILVA NETO et al., 2016). The biogenic formation pathway is favored in these environments due to physical processes related to exploration of soil by roots, which pressure mineral particles and promote their approximation during the growth process; and by chemical processes related to exudation of compounds that present agglutinating effect of solid soil particles (LOSS et al., 2015).

The results of this study corroborate the Batista et al. (2013) also verified higher percentages of physicogenic aggregate percentages for forest areas, but very low percentages of biogenic aggregates, even in the forest area, due to intrinsic characteristics of the soil. According to Bronick and Lal (2005), the soil structure can be significantly affected by management practices; and Cunha et al. (2011) showed that not only soil management, but the use of soil cover plants has significant effects on soil aggregation. Thus, the results found indicate a balanced proportion of aggregate formation pathways when considering the results of the forest area.

The weighted mean diameter (WMD) and geometric mean diameter (GMD) of biogenic and physicogenic aggregates of the crop areas were similar in the upper and lower sections of the landscape (Table 1). However, biogenic aggregates showed higher WMD and GMD. Fernandes et al. (2017) found similar results for areas of Atlantic Forest. Considering the areas in the upper section, the BO-F area had higher mean WMD and GMD. Despite no differences between formation pathways were found, the high aggregate stability in the BO-F area can be attributed to the biogenic formation pathway, since this area presented higher proportion of biogenic than physicogenic aggregates.

According to Silva Neto et al. (2016), the biological aggregation process is probably the most efficient for soil structural stability, and biogenic aggregates are important indicators of soil quality. The WMD and GMD found in the areas in the upper section were similar to those reported for areas with no-till system by Loss et al. (2014), who attributed the results to the accumulation of plant residues in the soil surface and consequent increase in soil organic matter contents, which combined with the high soil clay contents are cementing agents, favored soil aggregation. Considering that black oat is a grass species that has a fasciculate root system, it provides more approximation of soil particles under addition of chemical fertilizers. The root system growth can be potentialized and promote higher soil stability, as shown by the higher WMD and GMD of the BO-F area.

The WMD and GMD of the areas in the lower section were similar (Table 1). The biogenic and physicogenic aggregates in the forest area used as reference, which had not been subjected to anthropogenic actions, indicated better aggregate stability. According to Salton et al. (2008), aggregate stability is related to the soil use, and forest systems form naturally more stable aggregates. Rossi et al. (2015) evaluated the same area in 2013 and found lower WMD $(1.78 \mathrm{~mm})$ and GMD $(1.15 \mathrm{~mm})$ for the BO-F area. In the present study, a significant improvement in soil aggregation was found after two years of black oat crops, doubling the WMD and GMD. Therefore, the WMD and GMD found indicate that use of black oat crops, and the soil management of the crop areas increased aggregation, regardless the aggregation formation pathway. 
Table 1. Weighted mean diameter (WMD) and geometric mean diameter (GMD) of soil aggregates in crop and forest areas, considering their formation pathways.

\begin{tabular}{lcc}
\hline \multicolumn{1}{c}{ Areas } & WMD & GMD \\
\hline & \multicolumn{2}{c}{ mm } \\
\cline { 2 - 3 } & $3.611 \mathrm{~b}$ & Upper section \\
BO-N & $4.211 \mathrm{a}$ & $1.933 \mathrm{~b}$ \\
BO-F & 4.519 & $2.463 \mathrm{a}$ \\
FA & 5.85 & 3.529 \\
CV\% & & 13.92 \\
Formation pathways & $4.127 \mathrm{a}$ & \\
Biogenic & $3.682 \mathrm{a}$ & $2.472 \mathrm{a}$ \\
Physicogenic & 4.702 & $1.924 \mathrm{a}$ \\
Biogenic FA & 4.336 & 3.887 \\
Physicogenic FA & 11.80 & 3.171 \\
CV\% & & 30.16 \\
BO-F & $4.346 \mathrm{a}$ & \\
INT & $3.835 \mathrm{a}$ & $2.985 \mathrm{a}$ \\
FA & 4.778 & $2.355 \mathrm{a}$ \\
CV\% & 13.61 & 4.11 \\
Formation pathways & & 27.79 \\
Biogenic & $4.215 \mathrm{a}$ & \\
Physicogenic & $3.962 \mathrm{a}$ & $2.825 \mathrm{a}$ \\
Biogenic FA & 4.777 & $2.515 \mathrm{a}$ \\
Physicogenic FA & 4.779 & 4.113 \\
CV\% & 6.90 & 4.121 \\
\hline
\end{tabular}

Means followed by the same letter in the columns are not different by the Bonferroni test $(p<0.05)$. BO-N = black oat - not fertilized, BO-F = black oat - fertilized, INT (black oat-oilseed radish-vetch intercrop), FO-U (Forest area - upper section), FO-L (Forest area - lower section); $\mathrm{CV}=$ coefficient of variation.

The WMD and GMD of the areas in the lower section were similar (Table 1). The biogenic and physicogenic aggregates in the forest area used as reference, which had not been subjected to anthropogenic actions, indicated better aggregate stability. According to Salton et al. (2008), aggregate stability is related to the soil use, and forest systems form naturally more stable aggregates. Rossi et al. (2015) evaluated the same area in 2013 and found lower WMD $(1.78 \mathrm{~mm})$ and GMD $(1.15 \mathrm{~mm})$ for the BO-F area. In the present study, a significant improvement in soil aggregation was found after two years of black oat crops, doubling the WMD and GMD. Therefore, the WMD and GMD found indicate that use of black oat crops, and the soil management of the crop areas increased aggregation, regardless the aggregation formation pathway.

The analysis of soil chemical attributes and aggregate stability showed differences between the crop areas, but not between aggregate formation pathways within the areas (Table 2). The BO-F area in the upper section had presented higher $\mathrm{pH}$ than the other crop areas due to the greater biomass production, rhizodeposition, low-molecular-weight organic acids, and complexation of ions $\mathrm{H}^{+}$and $\mathrm{Al}^{3+}$ (FERNANDES et al., 2017). The lower results of the $\mathrm{BO}-\mathrm{N}$ area can be related to its higher $\mathrm{Al}^{+3}$ contents. The mean $\mathrm{pH}$ in the reference area were lower than that found in the black oat areas, which can be related to the constant root system renewal of the grasses that contribute positively to nutrients cycling and act in the complexation of exchangeable aluminum by the organic matter added to the system (BATISTA et al., 2013; SILVA NETO et al., 2016; FERNANDES et al., 2017).

The highest phosphorus (P) contents were found in the BO-F area in the upper and lower sections, denoting the effect of soil fertilization in this area for the implementation of black oat. In the lower section, it was due to the soil fertilization with NPK and poultry litter. According to Silva et al. (2011), poultry litter is a good source of nutrients that can substitute chemical $\mathrm{P}$ fertilization when properly managed. The organic and inorganic soil phosphorus fractions can be a source or drain for the soil solution, depending on their mineralogical characteristics, environmental conditions, soil fertilization, and soil management (SANTOS et al., 2008). In natural systems with no addition of phosphorus, $\mathrm{P}$ availability is related to the cycling of organic P. In fertilized soils, most available phosphorus is buffered by labile inorganic fractions (NOVAIS; SMITH, 1999). Thus, considering the addition of $\mathrm{P}$ fertilizers in the BO-F area, the results may be related to inorganic and organic $P$ accumulations with different binding energy levels (SANTOS et al., 2008). 
Table 2. Chemical attributes of aggregates in the $0-0.10 \mathrm{~m}$ soil layer of crop and forest areas, considering the aggregate formation pathways.

\begin{tabular}{|c|c|c|c|c|c|}
\hline Areas & $\mathrm{pH}\left(\mathrm{H}_{2} \mathrm{O}\right)$ & $\mathrm{Al}^{+3}$ & $\mathrm{H}+\mathrm{Al}$ & $\mathrm{P}$ & TOC \\
\hline & & \multicolumn{2}{|c|}{$\mathrm{cmol}_{\mathbf{c}} \mathrm{kg}$} & $\mathrm{mg} \mathrm{kg}^{-1}$ & $\mathrm{~g} \mathrm{~kg}^{-1}$ \\
\hline \multicolumn{6}{|c|}{ Upper section } \\
\hline BO-N & $4.43 \mathrm{~b}$ & $2.06 \mathrm{a}$ & $5.34 \mathrm{a}$ & $11.10 \mathrm{~b}$ & $19.41 \mathrm{~b}$ \\
\hline BO-F & $5.25 \mathrm{a}$ & $0.54 \mathrm{~b}$ & $3.46 \mathrm{a}$ & $34.21 \mathrm{a}$ & $25.45 \mathrm{a}$ \\
\hline FA & 4.25 & 2.85 & 6.90 & 5.51 & 24.03 \\
\hline $\mathrm{CV} \%$ & 8.53 & 39.52 & 40.84 & 21.24 & 21.07 \\
\hline \multicolumn{6}{|c|}{ Formation pathways } \\
\hline Biogenic & $4.93 \mathrm{a}$ & $1.36 \mathrm{a}$ & $4.45 \mathrm{a}$ & $23.27 \mathrm{a}$ & $22.65 \mathrm{a}$ \\
\hline Physicogenic & $4.75 \mathrm{a}$ & $1.23 \mathrm{a}$ & $4.35 \mathrm{a}$ & $22.04 \mathrm{a}$ & $22.22 \mathrm{a}$ \\
\hline Biogenic FA & 4.21 & 2.79 & 7.22 & 7.24 & 22.27 \\
\hline Physicogenic FA & 4.28 & 2.90 & 6.59 & 3.78 & 25.79 \\
\hline $\mathrm{CV} \%$ & 2.64 & 10.26 & 16.43 & 32.64 & 16.70 \\
\hline \multicolumn{6}{|c|}{ Lower section } \\
\hline $\mathrm{BO}-\mathrm{F}$ & $5.74 \mathrm{a}$ & $0.07 \mathrm{a}$ & $2.95 \mathrm{~b}$ & $105.37 \mathrm{a}$ & $26.35 \mathrm{a}$ \\
\hline INT & $5.48 \mathrm{a}$ & $0.14 \mathrm{a}$ & $3.25 \mathrm{a}$ & $41.82 \mathrm{~b}$ & $22.78 \mathrm{a}$ \\
\hline FA & 4.40 & 1.94 & 4.66 & 3.77 & 21.49 \\
\hline $\mathrm{CV} \%$ & 12.24 & 28.26 & 6.62 & 17.10 & 26.97 \\
\hline \multicolumn{6}{|c|}{ Formation pathways } \\
\hline Biogenic & $5.57 \mathrm{a}$ & $0.10 \mathrm{a}$ & $3.05 \mathrm{a}$ & $77.28 \mathrm{a}$ & $25.05 \mathrm{a}$ \\
\hline Physicogenic & $5.65 \mathrm{a}$ & $0.11 \mathrm{a}$ & $3.15 \mathrm{a}$ & $69.91 \mathrm{a}$ & $24.08 \mathrm{a}$ \\
\hline Biogenic FA & 4.37 & 1.85 & 4.92 & 4.52 & 19.72 \\
\hline Physicogenic FA & 4.44 & 1.94 & 4.39 & 3.03 & 23.27 \\
\hline $\mathrm{CV} \%$ & 5.83 & 12.47 & 4.22 & 8.90 & 7.66 \\
\hline
\end{tabular}

Means followed by the same letter in the columns are not different by the Bonferroni test $(\mathrm{p}<0.05)$. BO-F $=$ black oat - fertilized, BO-N = black oat - not fertilized, INT (black oat-oilseed radish-vetch intercrop), FO-L (Forest area - lower section), FO-U (Forest area - upper section), FA = forest area; TOC = total organic carbon; $\mathrm{CV}=$ coefficient of variation.

The higher total organic carbon (TOC) contents in the BO-F area in the upper section may be related to the effect of soil fertilization, which favors the development of the black oat root system, increasing soil organic matter contents. Steiner et al. (2012) evaluated the effect of soil fertilization for soil cover crops on the soil organic carbon stocks and found higher dry matter production for black oat crop when using soil fertilization, which increased soil organic carbon contents. Moreover, black oat crops present high potential of extract and recycle macronutrients, mainly, $\mathrm{N}, \mathrm{P}$, and $\mathrm{K}$, preventing their pronounced leaching or immobilization, making them available to subsequent crops (CRUSCIOL et al., 2008). According to Melo et al. (2011), black oat crops are a winter crop of high straw production and low decomposition rate due to its high $\mathrm{C}$ to $\mathrm{N}$ ratio $(>30)$. The straw added to the soil is decomposed by microorganisms, favoring the release of nutrients to the soil.

Another factor that may have contributed to the higher TOC contents in the BO-F area in the upper section is the higher proportion of biogenic aggregates found in this area. Although no difference in TOC contents was found between biogenic and physicogenic aggregates, biogenic aggregation contributes to the protection of soil organic matter (PULLEMAN et al., 2005). It is attributed to polysaccharides and humified macromolecules produced by microbial activity (COQ et al., 2007), which decrease decomposition rates, and increase soil organic carbon contents. In addition, the higher WMD and GMD in the BO-F area may have provided higher protection to organic matter and, thus, higher TOC contents. Batista et al. (2013) evaluated soil aggregate formation pathways and found positive correlation between biogenic aggregates and organic carbon contents. According to Brussaard et al. (2007), these aggregates are important sites for organic matter stabilization.

The different management systems used in the lower section had no significant effect on TOC 
contents; the crop areas had higher means than the forest area. However, the BO-F areas in both sections of the landscape had higher TOC contents, sum of bases, and base saturation, denoting the efficiency of this crop in cycling nutrients, mobilize cations, and fixing carbon in the soil. (MELO et al., 2011). The BO-F and INT areas had similar $\mathrm{pH}$ and $\mathrm{Al}^{+3}$ contents (main component of soil acidity in tropical regions). These areas had higher $\mathrm{pH}$ and lower $\mathrm{Al}^{+3}$ than those found for the forest area, denoting lower acidity for soils with black oat crops. These results are related to the efficiency of black oat crops in produce dry matter, which is converted into soil organic matter, and its decomposition releases organic compounds, which can complex $\mathrm{Al}^{+3}$.

The BO-F area in the upper section (Table 3) had higher $\mathrm{Ca}^{+2}, \mathrm{Mg}^{+2}$, and $\mathrm{Na}^{+}$contents, which resulted in different sum of bases and base saturation. The $\mathrm{Na}^{+}$were low and caused no problems; high amounts of this element is not beneficial for the plant nutrition. The $\mathrm{K}^{+}$contents found in the areas were similar. The higher $\mathrm{pH}$ in the $\mathrm{BO}-\mathrm{F}$ area is related to the lower $\mathrm{H}+\mathrm{Al}$ concentration, components of soil potential acidity, and to the complexation of $\mathrm{Al}^{+3}$ by the soil organic matter, since higher TOC and lower $\mathrm{Al}^{+3}$ contents were found in the BO-F area.

Table 3. Chemical attributes of aggregates in the layer $0-0.10 \mathrm{~m}$ of soils under crop and forest areas, considering the aggregate formation pathways.

\begin{tabular}{|c|c|c|c|c|c|c|c|}
\hline Areas & $\mathrm{Ca}^{+2}$ & $\mathrm{Mg}^{+2}$ & $\mathrm{~K}^{+}$ & $\mathrm{Na}^{+}$ & $\begin{array}{c}\text { Sum of } \\
\text { bases }\end{array}$ & $\begin{array}{c}\mathrm{CEC} \\
\mathrm{pH} 7.0\end{array}$ & $\begin{array}{c}\text { Base } \\
\text { saturation }\end{array}$ \\
\hline & \multicolumn{6}{|c|}{$\mathrm{cmol}_{\mathrm{c}} \mathrm{kg}$} & $\%$ \\
\hline & \multicolumn{6}{|c|}{ Upper section } & \\
\hline $\mathrm{BO}-\mathrm{N}$ & $0.27 \mathrm{~b}$ & $0.70 \mathrm{~b}$ & $0.36 \mathrm{a}$ & $0.02 \mathrm{~b}$ & $1.36 \mathrm{~b}$ & $6.70 \mathrm{a}$ & $21 \mathrm{~b}$ \\
\hline BO-F & $1.61 \mathrm{a}$ & $1.46 \mathrm{a}$ & $0.60 \mathrm{a}$ & $0.06 \mathrm{a}$ & $3.74 \mathrm{a}$ & $7.20 \mathrm{a}$ & $51 \mathrm{a}$ \\
\hline FA & 0.33 & 0.98 & 0.18 & 0.02 & 1.51 & 8.42 & 17 \\
\hline $\mathrm{CV} \%$ & 12.71 & 23.69 & 41.77 & 43.13 & 16.41 & 29.40 & 36.18 \\
\hline \multicolumn{8}{|l|}{ Formation pathways } \\
\hline Biogenic & $1.04 \mathrm{a}$ & $1.25 \mathrm{a}$ & $0.47 \mathrm{a}$ & $0.05 \mathrm{a}$ & $2.82 \mathrm{a}$ & $7.26 \mathrm{a}$ & $38 \mathrm{a}$ \\
\hline Physicogenic & $0.84 \mathrm{a}$ & $0.91 \mathrm{a}$ & $0.48 \mathrm{a}$ & $0.04 \mathrm{a}$ & $2.29 \mathrm{a}$ & $6.64 \mathrm{a}$ & $33 \mathrm{a}$ \\
\hline Biogenic FA & 0.07 & 0.08 & 0.21 & 0.03 & 1.10 & 8.32 & 13 \\
\hline Physicogenic FA & 0.59 & 1.16 & 0.15 & 0.02 & 1.93 & 8.51 & 21 \\
\hline \multirow[t]{2}{*}{$\mathrm{CV} \%$} & 5.52 & 16.87 & 23.18 & 27.95 & 9.57 & 13.83 & 17.84 \\
\hline & \multicolumn{7}{|c|}{ Lower section } \\
\hline BO-F & $3.15 \mathrm{a}$ & $2.18 \mathrm{a}$ & $1.19 \mathrm{a}$ & $0.12 \mathrm{a}$ & $6.63 \mathrm{a}$ & $9.59 \mathrm{a}$ & $69 a$ \\
\hline INT & $1.92 \mathrm{~b}$ & $1.49 \mathrm{~b}$ & $0.04 \mathrm{~b}$ & $0.06 \mathrm{~b}$ & $3.50 \mathrm{~b}$ & $6.75 \mathrm{~b}$ & $51 \mathrm{~b}$ \\
\hline FA & 0.07 & 0.80 & 0.02 & 0.03 & 0.92 & 5.58 & 17 \\
\hline $\mathrm{CV} \%$ & 30.38 & 21.60 & 38.82 & 17.65 & 25.20 & 15.49 & 11.43 \\
\hline \multicolumn{8}{|c|}{ Formation pathways } \\
\hline Biogenic & $2.55 \mathrm{a}$ & $1.87 \mathrm{a}$ & $0.72 \mathrm{a}$ & $0.09 \mathrm{a}$ & $5.23 \mathrm{a}$ & $8.29 \mathrm{a}$ & $61 \mathrm{a}$ \\
\hline Physicogenic & $2.51 \mathrm{a}$ & $1.79 \mathrm{a}$ & $0.51 \mathrm{a}$ & $0.09 \mathrm{a}$ & $4.90 \mathrm{a}$ & $8.05 \mathrm{a}$ & 59 a \\
\hline Biogenic FA & 0.08 & 0.88 & 0.03 & 0.03 & 1.01 & 5.93 & 17 \\
\hline Physicogenic FA & 0.07 & 0.72 & 0.02 & 0.03 & 0.83 & 5.23 & 16 \\
\hline $\mathrm{CV} \%$ & 7.48 & 12.79 & 23.76 & 12.23 & 11.46 & 8.06 & 3.61 \\
\hline
\end{tabular}

Means followed by the same letter in the columns are not different by the Bonferroni test $(\mathrm{p}<0.05)$. BO-N $=$ black oat - not fertilized, BO-F = black oat - fertilized, INT (black oat-oilseed radish-vetch intercrop), FO-U (Forest area - upper section), FO-L (Forest area - lower section); $\mathrm{CV}=$ coefficient of variation. Sum of bases $=\mathrm{Ca}^{+2}+\mathrm{Mg}^{+2}+$ $\mathrm{K}^{+}+\mathrm{Na}^{+}$; CEC pH 7.0 $=$Sum of bases $+\mathrm{H}+\mathrm{Al}$; Base saturation $=($ Sum of bases $/ \mathrm{CEC} \mathrm{pH} \mathrm{7.0)} \times 100$.

Areas used for black oat as soil cover are usually not properly fertilized. The results found in the present study show the high capacity of cycling nutrients of black oat crops, by the higher sum of bases and TOC contents, when compared to the secondary forest area used as reference. Black oat is one of the main plants used as soil cover due to its high efficiency in cycling of nutrients, and promotion of cation mobilization and chemical changes in the soil profile that increase nutrient availability (MELO et al., 2011).

The BO-F area in the lower section had higher $(p<0.05)$ basic cation contents $\left(\mathrm{Ca}^{+2}, \mathrm{Mg}^{+2}\right.$, $\mathrm{K}^{+}$, and $\mathrm{Na}^{+}$) than the intercrop area (INT). Thus, the sum of bases and base saturation were also higher in BO-F. The two crop systems had higher means than 
the reference area for all nutrients analyzed. In the upper section of the landscape, the higher means in the BO-F denote the efficiency of the crop in nutrient cycling. The significant difference in $\mathrm{K}^{+}$contents was probably related to the soil fertilization with poultry litter in the BO-F area. According to Melo et al. (2011), $\mathrm{K}^{+}$is one of the most cycled nutrients by black oat, being rapidly released to the soil as the straw is decomposed. This nutrient is not structurally bound to the plant tissue; thus, it is more rapidly cycled than the other nutrients (PAVINATO; ROSOLEM, 2008).

Similar to $\mathrm{K}^{+}$, the highest $\mathrm{P}$ contents were found in the BO-F area, with significant difference from the intercrop area. The results found by Rossi et al. (2015) also show high P contents for the BO-F area (41.2 and $27.1 \mathrm{mg} \mathrm{kg}^{-1}$ for the $0-0.5$ and $5-10 \mathrm{~m}$ layers). The results of the present study indicate a considerable increase in $\mathrm{P}$ contents in this area. The plant biomass on the soil surface due to the use of soil cover plants favors the cycling of $\mathrm{P}$ in the soil. According to Barros, Gomide and Carvalho (2013), soil cover plants improve soil quality because of increases in organic matter contents and nutrient cycling. However, the location of the areas in the lower section of the landscape can decrease the losses, since this section has sediment deposition and accumulation.

\section{CONCLUSIONS}

Management systems with soil fertilization and intercrop affect the biogenic aggregate formation pathway.

The weighted mean diameter and geometric mean diameter found indicated that the soil management with black oat as soil cover plants in crop areas improves soil structural quality, regardless of the aggregate formation pathway, and this improvement is associated with increases in organic carbon contents.

Black oat crops increase biogenic aggregate formation, which become reservoir of nutrients. The benefits of black oat crops to the soil do not depend on the position of the area in the landscape.

The soil chemical attributes of the areas evaluated were affected by the soil fertilization; however, this effect was not found for the aggregate formation pathways.

\section{ACKNOWLEDGEMENTS}

The authors thank the Brazilian Coordination for the Improvement of Higher Education Personnel (CAPES) for granting the postdoctoral scholarship to the first author, and for the financial support from of the Postgraduation Support Program; the Brazilian Agricultural Research Corporation (Embrapa
Agrobiology) through the Center of Research and Training for Farmers, in Nova Friburgo, RJ, Brazil, for the logistic and financial support; and to the farmers Josias (in memoriam), Adelson, Margareth, and Cicinho for allowing the study in their areas.

\section{REFERENCES}

AL-KAISI, M. M.; DOUELLE, A.; KWAWMENSAH, D. Soil microaggregate and macroaggregate decay over time and soil carbon change as influenced by different tillage systems. Journal of Soil and Water Conservation, 69: 574580,2014

BARRADAS, C. A. A. et al. Comportamento de adubos verdes de inverno na região serrana fluminense Pesquisa Agropecuária Brasileira, 36: 1461-1468, 2001.

BARROS, D. L.; GOMIDE, P. H. O.; CARVALHO, G. J. Plantas de cobertura e seus efeitos na cultura em sucessão. Bioscience Journal, 29: 308-318, 2013.

BATISTA, I. et al. Caracterização dos agregados em solos sob cultivo no Cerrado, MS. Semina: Ciências Agrárias, 34: 1535-1548, 2013.

BOCHNER, J. K. et al. Matéria orgânica e agregação de um Planossolo sob diferentes, coberturas florestais. Cerne, 14: 46-53, 2008.

BRANDÃO, E. D.; SILVA, I. F. Formação e estabilização de agregados pelo sistema radicular de braquiária em um Nitossolo Vermelho. Ciência Rural, 42: 1193-1199, 2012.

BRONICK, C. J.; LAL, R. Soil structure and management: a review. Geoderma, 124: 3-22, 2005.

BRUSSAARD, L. et al. Soil fauna and soil function in the fabric of the food web, Pedobiologia, 50: 447462, 2007.

BULLOCK, P. et al. Handbook for soil thin section description. Albrighton, England: Waine Research Publications, 1985. $152 \mathrm{p}$.

COQ, S. et al. Earthworm activity affects soil aggregation and organic matter dynamics according to the quality and localization of crop residues - An experimental study (Madagascar). Soil Biology \& Biochemistry, 39: 2119-2128. 2007.

CRUSCIOL, C. A. C. et al. Taxas de decomposição e de liberação de macronutrientes da palhada de aveia preta em plantio direto. Bragantia, 67: 481489, 2008. 
CUNHA, E. Q. et al. Sistemas de preparo do solo e culturas de cobertura na produção orgânica de feijão e milho. Revista Brasileira de Ciência do Solo, 35: 589-602, 2011.

DEMARCHI, J. C.; PERUSI, M. C.; PIROLI, E. L. Análise da estabilidade de agregados de solos da microbacia do Ribeirão São Domingos, Santa Cruz do Rio Pardo, SP, sob diferentes tipos de uso e ocupação. Pesquisa Aplicada \& Agrotecnologia, 4: 7-29, 2011.

DONAGEMA, G. K. et al. Manual de métodos de análises de solos. 2. ed. Rio de Janeiro, RJ: Embrapa Solos, 2011. 230 p. (Documentos Embrapa Solos, 132).

FERNANDES, J. C. F. et al. Characterization of biogenic, intermediate and physicogenic soil aggregates of areas in the brazilian Atlantic Forest. Revista Caatinga, 30: 59-67, 2017.

FERREIRA, E. B.; CAVALCANTI, P. P.; NOGUEIRA, D. A. ExpDes.pt: Experimental Designs pacakge (Portuguese). R package version 1.1.2. 2013.

FERREIRA C. R. et al. Dynamics of soil aggregation and organic carbon fractions over 23 years of no-till management. Soil \& Tillage Research, 198: 1-9, 2020.

LOSS, A. et al. Carbon, nitrogen and natural abundance of $13 \mathrm{C}$ and $15 \mathrm{~N}$ in biogenic and physicogenic aggregates in a soil with 10 years of pig manure application. Soil \& Tillage Research, 166: 52-58, 2017.

LOSS, A. et al. Agregação, matéria orgânica leve e carbono mineralizável em agregados do solo. Revista de la Facultad de Agronomía, 113: 1-8, 2014.

LOSS, A. et al. Carbono orgânico total e agregação do solo em sistema de plantio direto agroecológico e convencional de cebola. Revista Brasileira de Ciência do Solo, 39: 1212-1224, 2015.

MELO, A. V. et al. Extração de nutrientes e produção de biomassa de aveia-preta cultivada em solo submetido a dezoito anos de adubação orgânica e mineral. Semina: Ciências Agrárias, 32: 411-420, 2011.

MELO, T. R. et al. Biogenic aggregation intensifies soil improvement caused by manures. Soil \& Tillage Research, 190: 186-193, 2019.

NOVAIS, R. F.; SMYTH, T. J. Fósforo em solo e planta em condições tropicais. 1 ed. Viçosa, MG:
Universidade Federal de Viçosa, 1999. 399 p.

PAVINATO, P. S.; ROSOLEM, C. A. Disponibilidade de nutrientes no solo: decomposição e liberação de compostos orgânicos de resíduos vegetais. Revista Brasileira de Ciência do Solo, 33: 911-920, 2008

PULLEMAN, M. M.; MARINISSEN, J. C. Y. Physical protection of mineralizable $\mathrm{C}$ in aggregates from long-term pasture and arable soil. Geoderma, 120: 273-282, 2004.

PULLEMAN, M. M. et al. Earthworms and management affect organic matter incorporation and microaggregate formation in agricultural soils. Applied Soil Ecology, 29: 1-15, 2005.

R DEVELOPMENT CORE TEAM. R: A language and environment for statistical computing. $\mathrm{R}$ Foundation for Statistical Computing, Vienna, 2015.

ROSSI, C. Q. et al. Atributos químicos e físicos de solo cultivado com oleráceas em microbacia hidrográfica, após desastre ambiental. Revista Brasileira de Ciência do Solo, 39: 1764-1775, 2015.

SALTON, J. C. et al. Agregação e estabilidade de agregados do solo em sistemas agropecuários em mato grosso do sul. Revista Brasileira de Ciência do Solo, 32: 11-21, 2008.

SANTOS, D. R. D. et al. Factors affecting the phosphorus availability and the fertilization management in no-tillage system. Ciência Rural, 38: 576-586, 2008.

SECRETARIA DE ESTADO DE AGRICULTURA E PECUÁRIA - SEAPEC-RJ. 2011. Agricultura Emergência - Diagnóstico do impacto das chuvas nas áreas agrícolas da região serrana do estado do Rio de Janeiro. Disponível em: < http:// www.rj.gov.br>. Acesso em: 15 jun. 2012.

SILVA, T. R. et al. Cultivo do milho e disponibilidade de $\mathrm{P}$ sob adubação com cama-defrango. Revista Brasileira de Engenharia Agrícola e Ambiental, 15: 903-910, 2011.

SILVA, R. F. et al. Fauna edáfica influenciada pelo uso de culturas e consórcios de cobertura do solo. Pesquisa Agropecuária Tropical, 2: 130-137, 2013.

SILVA NETO, et. al. Aggregate formation and soil organic matter under different vegetation types in Atlantic Forest from Southeastern Brazil. Semina: Ciências Agrárias, 37: 3927-3939, 2016. 
SIX, J. et al. Soil organic matter, biota and aggregation in temperate and tropical soils: effects of tillage. Agronomie, 22: 755-775, 2002.

STEINER, F. et al. Estoque de carbono orgânico no solo afetado por adubação orgânica e sistemas de culturas no Sul do Brasil. Semina: Ciências Agrárias, 33: 2775-2788, 2012.

TAVARES FILHO, J. et al. Atributos de solo determinantes para a estimativa do índice de estabilidade de agregados. Pesquisa Agropecuária Brasileira, 47: 436-441, 2012.

VEZZANI, F. M.; MIELNICZUK, J. Agregação e estoque de carbono em Argissolo submetido a diferentes práticas de manejo agrícola. Revista Brasileira de Ciência do Solo, 35: 213-223, 2011.

YEOMANS, J. C.; BREMNER, J. M. A. rapid and precise method for routine determination of organic carbon in soil. Communications in Soil Science and Plant Analisis, 19: 1467-1476, 1988. 